\title{
System for performance assessment of solar home systems
}

\author{
Sistema para la evaluación del desempeño de sistemas \\ solares domésticos
}

\author{
Sistema de avaliação do desempenho de sistemas \\ solares domésticos
}

\section{Yecid Alfonso Muñoz Maldonado ${ }^{1}$ María De Los Ángeles Pinto Calderón² Carlos Eduardo Vera Suárez ${ }^{3}$}

Received: August $25^{\text {th }}, 2020$ Accepted: November $5^{\text {th }}, 2020$

Available: May $5^{\text {th }}, 2021$

How to cite this article:

Y.A. Muñoz Maldonado, M.A. Pinto Calderón, C.A. Vera Suárez, "System for Performance Assessment of Solar Home Systems," Revista Ingeniería Solidaria, vol. 17, no. 2, 2021. doi: https://doi.org/10.16925/2357-6014.2021.02.01

Research article. https://doi.org/10.16925/2357-6014.2021.02.01

1 Universidad Autónoma de Bucaramanga, Colombia.

Email: ymunoz294@unab.edu.co

ORCID: https://orcid.org/0000-0002-5213-1884

https://scienti.minciencias.gov.co/cvlac/visualizador/generarCurriculoCv.do?cod_rh= 0001478388)

2 Universidad Autónoma de Bucaramanga, Colombia. Email: mpinto12@unab.edu.co oRCID: https://orcid.org/0000-0002-2181-5546

https://scienti.minciencias.gov.co/cvlac/visualizador/generarCurriculoCv.do?cod_rh= 0000156056)

3 Universidad Autónoma de Bucaramanga, Colombia.

Email: cvera678@unab.edu.co

ORCID: https://orcid.org/0000-0001-8593-9567

https://scienti.minciencias.gov.co/cvlac/visualizador/generarCurriculoCv.do?cod_rh= 0001647505) 


\section{Abstract}

Introduction: This article is the product of the investigation "Development of a photovoltaic pilot system for performance assessment of isolated systems in the Renewable Energy Laboratory at UNAB" developed at the Universidad Autónoma de Bucaramanga (UNAB) in 2019, considering that off-grid solar home systems (SHS) are a feasible alternative in rural remote areas, where access to electric power is limited due to the lack of a power grid, and the importance of monitoring its performance for a successful implementation of a PV system.

Objective: The objective is to develop a PV test system for an off-grid solar home system (SHS) performance assessment.

Methods: For the development, a case study is analyzed based on the behavior of a user's daily demand in the rural area Hato Corozal, Casanare. Design aspects of the system are also elaborated. Key performance parameters identified for monitoring are solar irradiance, power generation, energy consumption and battery charge status. Two scenarios of daily demand behavior are analyzed to evaluate the influence of load shifting on the performance of the system.

Results: The applied design criteria were validated obtaining that the sized system satisfied the energy requirement without a battery's depth of discharge (DOD) deeper than specified, showing the capacity of the system to make studies in longer periods with the possibility of generating different demand behavior scenarios.

Conclusions: The designed system presents a performance ratio of 0.77 when a daily consumption is considered, while when shifting loads to coincide with higher irradiance, the PR was 0.95 . In both cases, the state of charge (SoC) was higher than $79 \%$, maintaining a DOD of the battery bank according to that specified in the sizing. The system presents excess energy that can be used by expanding the capacity of the battery bank. Findings suggest that a higher performance ratio is obtained when coinciding consumption peaks with the hours of higher solar radiation.

Originality: The implementation of a system that validates the design criteria and evaluates the performance of an off-grid solar home systems (SHS) are presented for rural areas.

Limitations: The lack of information in rural areas of the country.

Keywords: off-grid, performance, photovoltaic, rural, solar home system.

\section{Resumen}

Introducción: El presente artículo es producto de la investigación "Desarrollo de un sistema fotovoltaico piloto para evaluar el desempeño de sistemas aislados en el Laboratorio de Energías Renovables, UNAB" desarrollado en la Universidad Autónoma de Bucaramanga (UNAB) en 2019, considerando que los sistemas solares domésticos aislados (SHS) son una alternativa viable en áreas rurales remotas, donde el acceso a la energía eléctrica es limitado debido a la falta de red eléctrica.

Objetivo: El objetivo es desarrollar un sistema fotovoltaico piloto para evaluar el rendimiento de sistemas solares domésticos aislados

Metodología: Para el desarrollo se analiza un caso de estudio basado en el comportamiento de la demanda diaria de un usuario en el área rural Hato Corozal, Casanare. Se elaboran aspectos de diseño del sistema. Los parámetros de rendimiento clave identificados para ser monitoreados son la irradiación solar, la generación de energía, el consumo de energía y el estado de carga de la batería. Se analizan dos escenarios de comportamiento de la demanda diaria para evaluar la influencia del desplazamiento de cargas en el rendimiento del sistema.

Resultados: Se validaron los criterios de diseño aplicados, obteniendo que el sistema dimensionado cumple con el requerimiento energético sin que la profundidad de descarga DOD de la batería sea mayor a la es- 
pecificada, demostrando así la capacidad del sistema para realizar estudios en períodos más largos con la posibilidad de generar diferentes escenarios de comportamiento de la demanda.

Conclusiones: El sistema diseñado presenta un ratio de rendimiento PR de 0,77 cuando se considera un consumo diario, mientras que al desplazar cargas para coincidir con la irradiancia más alta el PR fue de 0,95. En ambos casos, el estado de carga SoC fue superior al $79 \%$, manteniendo un DOD del banco de baterías según lo especificado en el dimensionamiento. El sistema presenta excedentes de energía que se pueden aprovechar aumentando la capacidad del banco de baterías. Los hallazgos sugieren que se obtiene una relación de rendimiento más alta al coincidir los picos de consumo con las horas de mayor radiación solar.

Originalidad: Se presenta la implementación de un sistema que valida los criterios de diseño y evalúa el desempeño de un sistema solar doméstico aislado (SHS) para áreas rurales.

Limitaciones: La falta de información en las zonas rurales del país.

Palabras clave: aislado, rendimiento, fotovoltaica, rural, sistema solar doméstico.

\section{Resumo}

Introdução: Este artigo é produto da pesquisa "Desenvolvimento de um sistema fotovoltaico piloto para avaliação do desempenho de sistemas isolados no Laboratório de Energias Renováveis, UNAB" desenvolvida na Universidade Autônoma de Bucaramanga (UNAB) em 2019, considerando que os sistemas Off Os painéis solares domésticos da rede (SHS) são uma alternativa viável em áreas rurais remotas, onde o acesso à energia elétrica é limitado devido à falta de energia da rede.

Objetivo: 0 objetivo é desenvolver um sistema fotovoltaico piloto para avaliar o desempenho de sistemas solares residenciais isolados.

Metodologia: Para o desenvolvimento, é analisado um estudo de caso baseado no comportamento da demanda diária de um usuário na área rural Hato Corozal, Casanare. Aspectos de design do sistema são elaborados. Os principais parâmetros de desempenho identificados a serem monitorados são irradiação solar, geração de energia, consumo de energia e estado de carga da bateria. Dois cenários de comportamento da demanda diária são analisados para avaliar a influência do deslocamento de carga no desempenho do sistema.

Resultados: Os critérios de projeto aplicados foram validados, obtendo-se que o sistema dimensionado atende ao requisito de energia sem que a profundidade de descarga DOD da bateria seja maior que a especificada, demonstrando assim a capacidade do sistema de realizar estudos em períodos mais longos com o possibilidade de gerar diferentes cenários de comportamento da demanda.

Conclusões: 0 sistema projetado apresenta um índice de desempenho de RP de 0,77 quando considerado o consumo diário, enquanto ao movimentar cargas para coincidir com a maior irradiância, o RP foi de 0,95. Em ambos os casos, o estado de carga do SoC foi superior a 79\%, mantendo um DOD do banco de baterias conforme especificado no dimensionamento. 0 sistema possui excesso de energia que pode ser aproveitado aumentando a capacidade do banco de baterias. Os resultados sugerem que uma maior taxa de desempenho é obtida quando os picos de consumo coincidem com as horas de maior radiação solar.

Originalidade: Apresenta-se a implementação de um sistema que valida os critérios de projeto e avalia o desempenho de um sistema solar residencial isolado (SHS) para áreas rurais.

Limitações: A falta de informação nas zonas rurais do país.

Palavras-chave: isolado, desempenho, fotovoltaico, rural, sistema solar residencial. 


\section{INTRODUCTION}

In recent years, renewable energy projects such as solar, wind, hydro and biomass have begun attracting worldwide attention and replacing energy generation from fossil fuels such as oil, coal and gas [1], leading to its implementation being widely encouraged by their integration advantages as a solution to the increase in energy demand and a need to reduce greenhouse gas emissions [2].

Solar photovoltaic (PV) energy is considered a good alternative for rural remote areas where there is no power grid and for off-grid applications at a small scale; socalled solar home systems (SHS), which are used to supply the lack of electric power in developing countries [3]. A typical SHS consists of a solar generator (PV module), inverter, battery bank and charge controller, as well as the connected appliances. Solar PV modules charge the batteries during the daytime to supply the night consumption, while the charge controller manages the input and output energy of the battery bank [4], [5].

Colombia is a developing country that receives solar radiation almost throughout the year with an annual mean of $4.5 \mathrm{kWh} / \mathrm{m}^{2} /$ day over its territory [6]-[8]. Despite having a huge scope of solar energy generation, there is still a lack of energy supply with about $51 \%$ of the national territory being formed of remote rural or non-interconnected zones (ZNI for its abbreviation in Spanish) [9]. Less than 3\% of the population in the country is supplied with this type of energy, thereby identifying a deficit in the three elements that drive PV development in a country: politics, research and monitoring [10].

This article presents the design of a PV test system for off-grid solar home system (SHS) performance assessment, analyzing a case study based on the behavior of a user's daily demand in the rural area Hato Corozal, Casanare.

\subsection{Literature review or research background}

Considering that photovoltaic systems are characterized by their easy installation, modular installations and energy independence provided to users [11], [12] they represent a viable alternative for grid-tied and off-grid PV systems that were already in operation and located in remote areas [13]-[15]. Shiva \& Sudhakar (2015) presented a performance analysis of $10 \mathrm{MW}$ photovoltaic system connected to a power grid and analyzed the performance of a large grid-tied system in operation as a parameter that could assist in the design, operation and maintenance of new systems connected to the electrical grid, validating experimental results with the support of software such as PVSyst and SolarGis [13]. Querikiol \& Taboada (2018) studied the operation of an 
off-grid system in a rural remote area, monitoring different variables such as battery voltage, PV voltage, battery current, energy generated, battery state of charge, etc., using Homer Pro software for optimization of the solar system [14]. Aghenta \& Iqbal (2019) present the design of the PV system analyzing in detail the user's loads, number of appliances, number of people, location, solar resource, weather variables and the integration of other energy sources such as diesel generation [15].

An existing solar PV 200 kW power plant in India was studied for its off-grid and on-grid configurations in order to analyze their performance parameters through measured data such as annual energy yield [16]. Muhammad et al. (2018) simulated in PVsyst and compared the performance that a stand-alone PV system would have in two geographical sites (Quetta, Pakistan and Copiapó-Chamonate, Chile), analyzing performance ratio, solar fraction, energy supplied to the load, etc. [2].

There are also several projects developed in rural or non-interconnected zones [10], [17], [18], however, it is not common to find a performance assessment of the system in its different stages, while in literature research there is not enough information available about the performance of solar home systems [19]. In this way it is difficult to know if the installed systems are functioning efficiently, thus it is being assumed that sizing criteria are precise.

It is also important to consider that effective component sizing ensures a reliable, proper and economical design [20]-[23]. Monitoring the performance and loss factors of PV systems is important to assess overall efficiency and to enhance productivity [24], thus a successful implementation of solar PV systems involves knowledge on their operational performance under varying climatic condition [25].

\section{MATERIALS AND METHODS}

\subsection{Methods}

\subsubsection{Energy requirement assessment}

To determine the daily energy requirement, $E_{\text {daily }}$ (in Wh/day), it was necessary to identify all the household electrical loads with their wattage and the mean amount of time they were used in a day as shown in Table 1. An approximate total power consumption of $0.90 \mathrm{~kW}$ and a daily energy requirement of $2.54 \mathrm{kWh} /$ day was obtained, which coincides with the value monitored in Hato Corozal, Colombia [26] and the $2.67 \mathrm{kWh} /$ day reported for rural users (strata 1) in Casanare department [27]. 
Table 1. Load and energy requirements assessment

\begin{tabular}{lcccc}
\hline $\begin{array}{c}\text { Load/ } \\
\text { Appliance }\end{array}$ & Quantity & $\begin{array}{c}\text { Power } \\
\text { consumption (W) }\end{array}$ & $\begin{array}{c}\text { Daily usage } \\
\text { hours (h/day) }\end{array}$ & $\begin{array}{c}\text { Daily energy } \\
\text { consumption (Wh/day) }\end{array}$ \\
\hline Lights & 6 & 15 & 4.0 & 360 \\
\hline Pump & 1 & 310 & 0.5 & 155 \\
\hline Fridge & 1 & 140 & 10.0 & 1.400 \\
\hline Blender & 1 & 220 & 0.2 & 44 \\
\hline Cell phone & 1 & 6 & 2.0 & 12 \\
\hline Radio & 1 & 16 & 6.0 & 96 \\
\hline Television & 1 & 50 & 5.0 & 250 \\
\hline Decoder & 1 & 15 & 5.0 & 75 \\
\hline Fan & 1 & 50 & 3.0 & 150 \\
\hline
\end{tabular}

Source: own work. Based on data from [26]

\subsubsection{Load monitoring}

Once the sizing and selection of the PV system components were carried out, loads were programmed by timers that allowed for them to be turned on/off at specific times to emulate the daily load curve. Figure 1a was followed for the connection of the components with the PentaMetric monitoring tool to analyze system performance, which has a three shunt that measures hourly current data and two connectors that measure voltage, energy and temperature from the batteries and PV modules. For the inverter, only current was measured, so the energy was calculated considering that the inverter voltage is the same as the battery bank voltage. Solar radiation was also monitored with a weather station available in the renewable energy laboratory of the Universidad Autónoma de Bucaramanga, UNAB and monthly data were obtained.

Two cases were analyzed, for the first one or Case-1 the total daily consumption of a user was considered without taking into account the behavior of their electrical loads and the hours when their consumption peaks are presented, while in Case-2 the user shifts their highest consumption to the daytime, seeking to coincide them with the hours of higher solar radiation so that it adapts to the characteristic load curve of the area.

\subsection{Materials}

The inverter charger used is a TECA IIP-241000BF with $1 \mathrm{~kW}$ of rated power and $3 \mathrm{~kW}$ of surge power, which allows for connection to the power grid to receive energy and to charge the batteries while supplying the demand of the charges. The four parallel-connected PV modules are JAP72S01-325SC with a rated power of $325 \mathrm{~W}$. Then, 
four Magna MA12-100 batteries were selected; two in series to increase the DC bus voltage to $24 \mathrm{~V}$ and two in parallel to increase the capacity of the battery bank [28]. The solar charge controller is the Acacia ICM-4024150 with a maximum current capacity of $40 \mathrm{~A}$. The final installation and specifications of the PV system are shown in Figure $1 \mathrm{~b}$ and Table 2, respectively. The performance ratio PR considers the possible losses of the system and it was also calculated [29], [30].
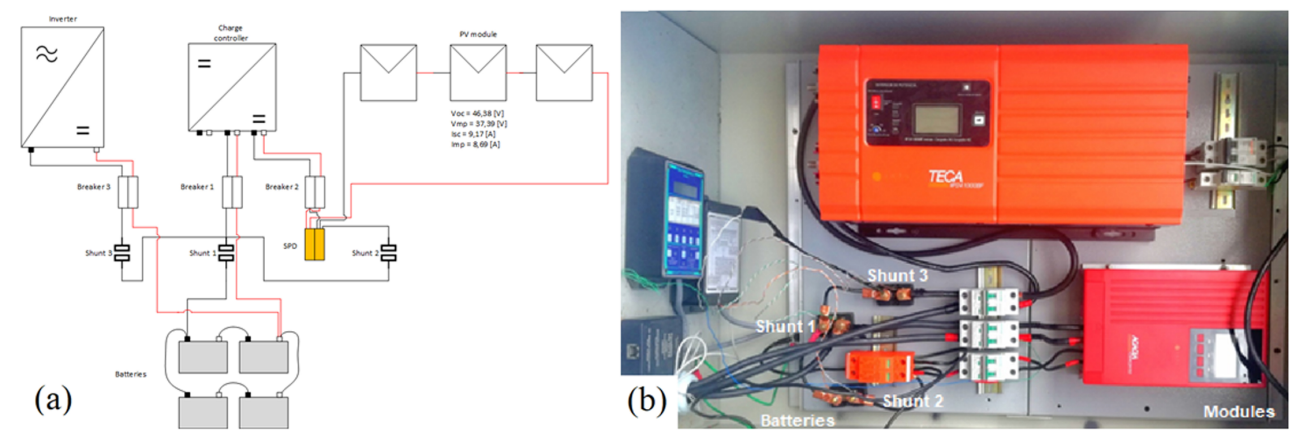

Figure 1. PV system layout (a) and final installation (b) Source: The Author.

Table 2. Specifications of the PV system

\begin{tabular}{cc}
\hline Component & Capacity \\
\hline PV modules & $1300 \mathrm{~W}$ \\
\hline Inverter & $1000 \mathrm{~W}$ \\
\hline Battery bank & $200 \mathrm{Ah}$ \\
\hline Charge controller & $40 \mathrm{~A}$ \\
\hline Specified maximum DOD & 0.7 \\
\hline Overall PR & 0.7 \\
\hline
\end{tabular}

Source: own work.

\section{RESULTS}

According to the behavior of the proposed system, the mean energy consumption was $2.41 \mathrm{kWh} /$ day. For Case-1, Figure 2 was obtained, where the solar radiation behavior and the PV supply of the system can be shown. A peak generation of $587 \mathrm{Wh}$ was reached at 9:00 $\mathrm{h}$ with a solar irradiance of $776 \mathrm{~W} / \mathrm{m}^{2}$ and a $\mathrm{PV}$ performance ratio of 0.77 . The highest solar irradiance, of $864 \mathrm{~W} / \mathrm{m}^{2}$, was presented at $12: 00 \mathrm{~h}$ and generated 269 Wh with a PR of 0.32 given the low consumption and full state of charge (SoC) of the battery bank. After 14:00 h, the PR was in the range of 0.70 and 0.93 with 
solar irradiance less than $250 \mathrm{~W} / \mathrm{m}^{2}$. A difference between the available solar potential and the PV supply was presented, since not all the energy generated was demanded by the system.

Figure 3 presents the battery's SoC and its respective voltage. Battery voltage was maintained in the range of 25.8 to $27.4 \mathrm{~V}$ from 10:00 to $18: 00 \mathrm{~h}$ due to the PV generation supplied loads and charged the battery bank in this period. The minimum SoC was $79 \%$. This means the DOD was not deeper than that specified in the sizing. The peak voltage and highest $\mathrm{SoC}$ was presented at $8: 30 \mathrm{~h}$ with values of $28.4 \mathrm{~V}$ and $118 \%$ respectively, which happens one hour after the highest generation, as shown in Figure 2.

For Case-2, Figure 3 shows a peak generation of $738 \mathrm{Wh}$, reached at 10:00 $\mathrm{h}$ with the highest solar irradiance of $742 \mathrm{~W} / \mathrm{m}^{2}$ and a PV performance ratio of 0.95 . The hours of highest solar irradiance (from 9:00 am - 12:00 pm) presented a high performance factor, due to the coinciding consumption peaks. The PV supply and radiation relationship were favorable for the system due to the solar resource was used in a greater proportion; it means the PR was better than in Case-1.

Figure 4 presents a maximum in battery voltage and SoC of $28.6 \mathrm{~V}$ and $103 \%$ respectively at 12:00 h, after two hours of the maximum energy consumption. The minimum SoC was $80 \%$, similar to Case-1, however, in this second case it was possible to maintain a voltage level higher than $26 \mathrm{~V}$ from 8:00 to 15:00 h. The state of charge coincided with the behavior in Figure 2, reflecting a slight gap between the curve of PV supply and solar radiation.

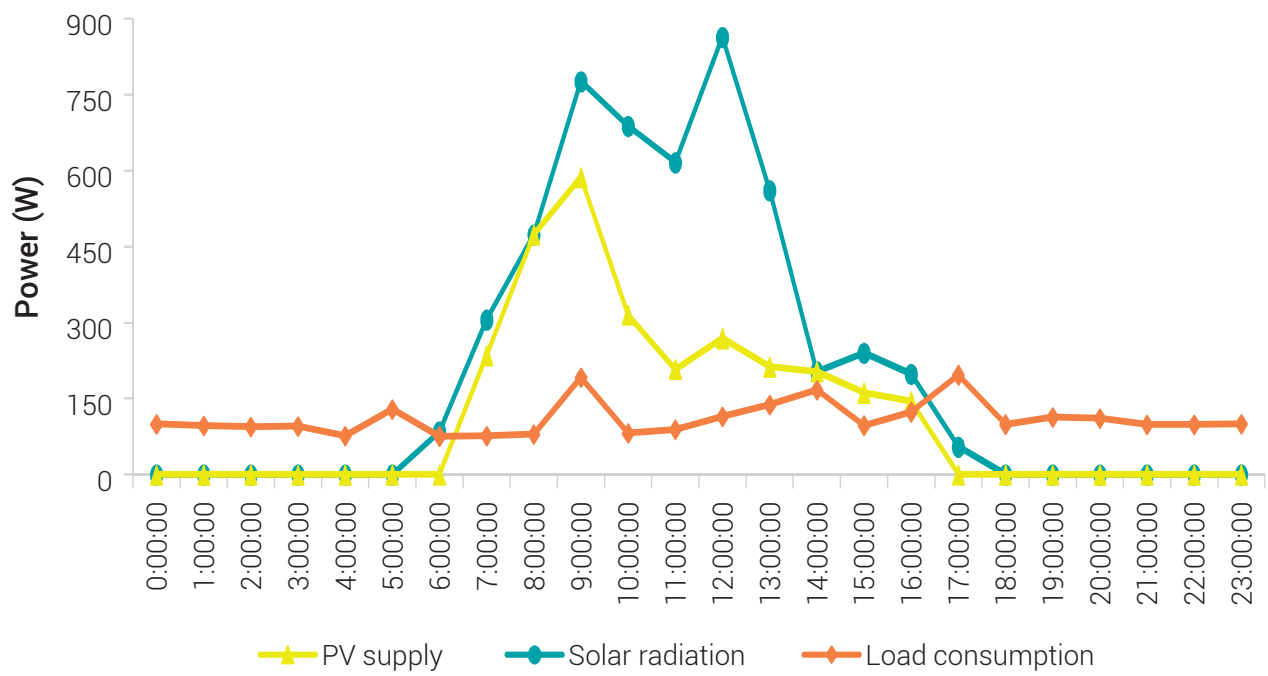

Figure 2. PV supply, solar radiation, and load curve (Case-1)

Source: own work. 


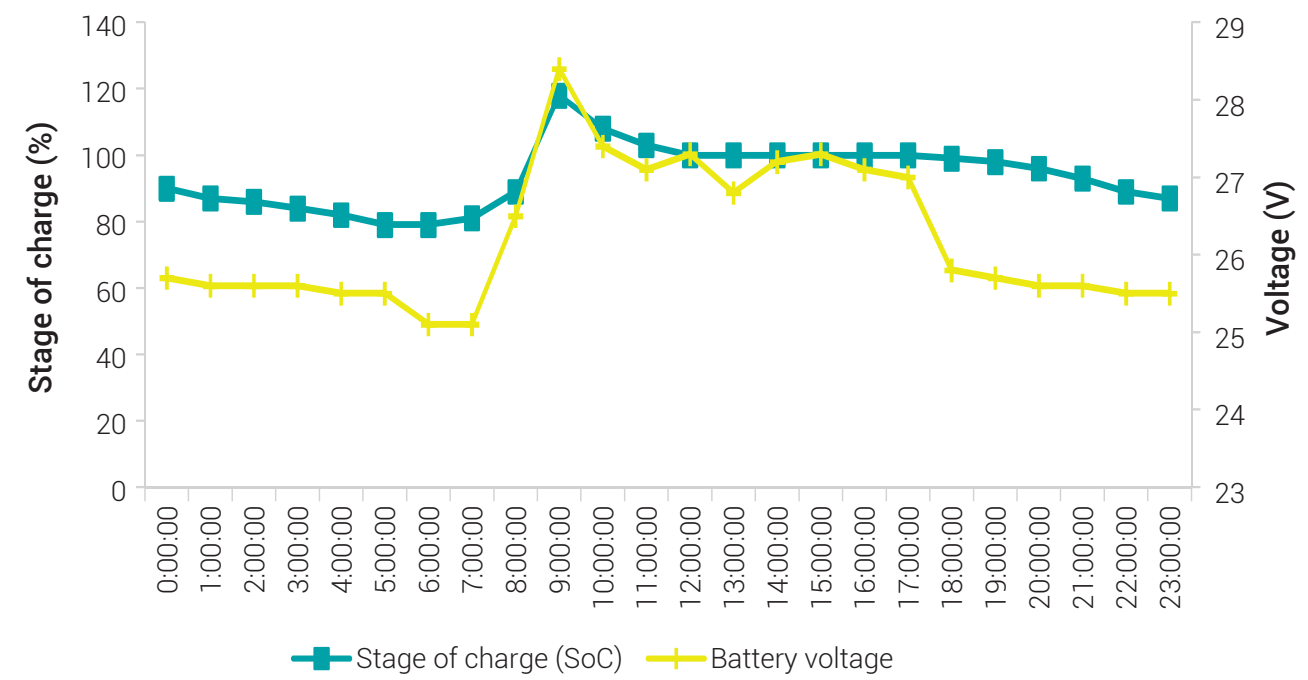

Figure 3. State of charge of battery bank (Case-1)

Source: own work.

\section{DISCUSSION AND CONCLUSIONS}

A system for performance assessment of solar home systems (SHS) was designed, sized and implemented for monitoring their performance parameters through measured data such as solar radiation, a battery's state of charge (SoC) and PV generation since most of the studies have been done either for grid-tied or off-grid PV systems already in operation.

The sized system satisfies the energy requirement without a DOD deeper than expected. In Case-1 a PR of 0.77 was obtained, nevertheless this value decreased to 0.70 despite having a good solar resource due to a low energy consumption by the loads and the full battery bank SoC; this then increased when the energy required exceed the PV generation. In Case-2 the PR was 0.95. In both cases, the SoC was higher than $79 \%$.

It was found that the excess solar energy not demanded or stored by the system affects its performance in a negative way due to an undersized battery bank, therefore it is necessary to expand the capacity of the battery bank. 


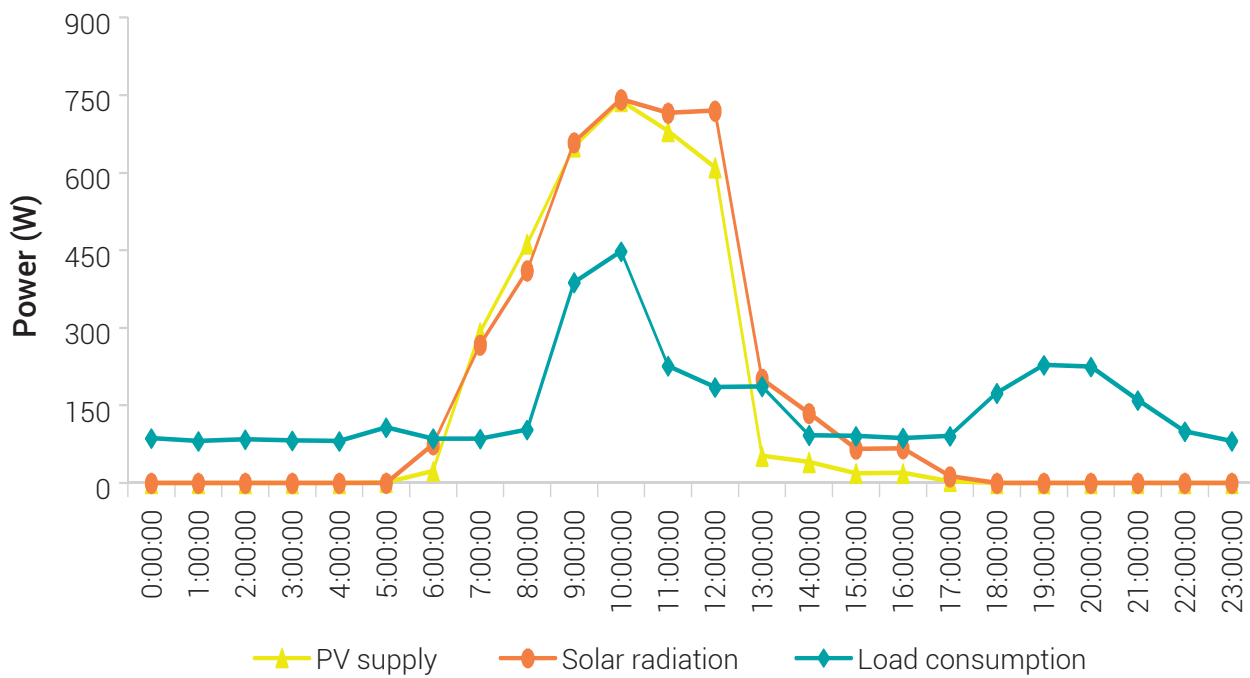

Figure 3. PV supply, solar radiation, and load curve (Case-2)

Source: own work.

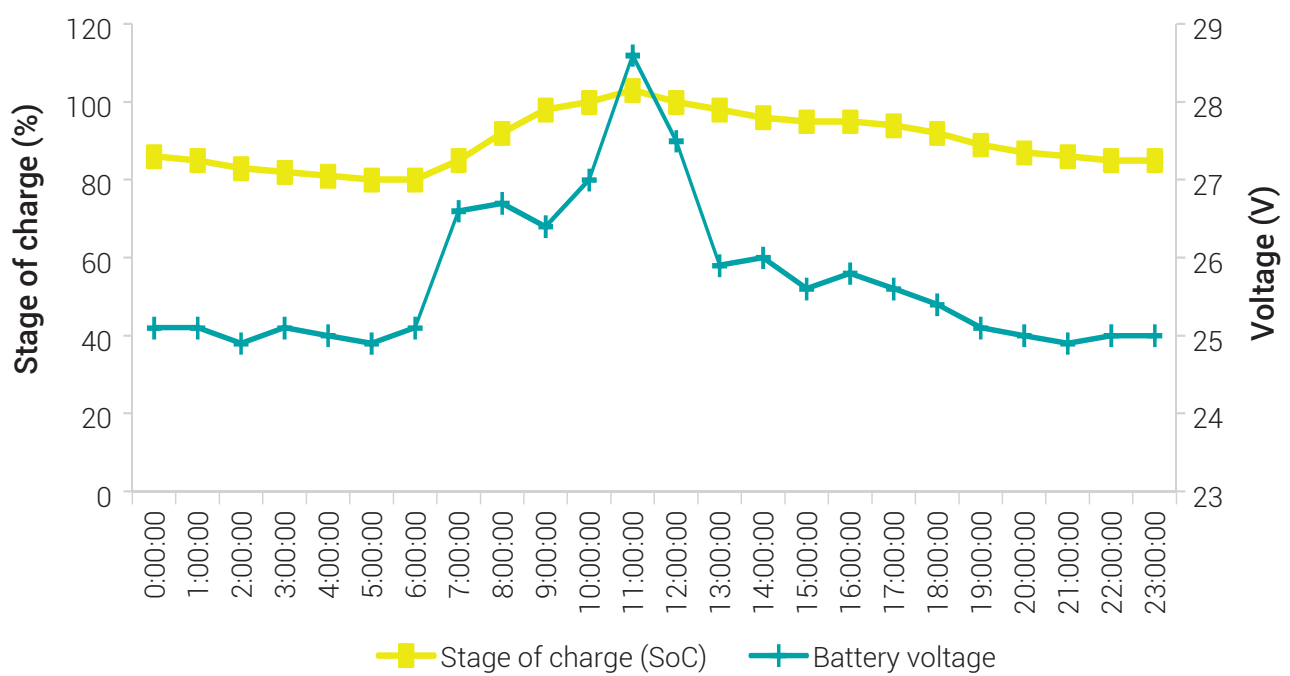

Figure 4. State of charge of battery bank (Case-2)

Source: own work.

A higher performance of the system is obtained when considering an hourly consumption and load shifting during its operation in such a way that the consumption peaks coincide with the hours of higher solar radiation, as this takes advantage of its generation potential (ratio of available radiation and energy generated). However, in this study the SoC of the batteries did not vary considerably between an hourly 
distribution of charges and a total daily consumption value because the nocturnal consumption peaks were not greater than the daytime ones; for this reason, in the event of a load curve with peaks centered on night hours, the proposed charge values could not be guaranteed and the useful life of the batteries could be affected.

This system is configurable to operate with the electrical network in case it extends to the rural zone, offering interactivity with the network to develop smart grid strategies. Findings in this study suggest that sizing with appropriate performance parameters helps in optimizing factors such as associated costs, component operation and lifespan.

\section{REFERENCES}

[1] M. Kamran, "Current status and future success of renewable energy in Pakistan," Renewable and Sustainable Energy Reviews, vol. 82, pp. 609-617, 2018, doi: https://doi.org/10.1016/j. rser.2017.09.049.

[2] T. Z. Muhammad, K. Cheng, and X. Y. Ma, "Modelling and simulation for installation feasibility of standalone photovoltaic system for Quetta, Pakistan," IOP Conference Series: Earth and Environmental Science, vol. 188, no. 1, pp. 1-7, Oct. 2018, doi: https://doi. org/10.1088/1755-1315/188/1/012008.

[3] V. Salas, E. Olías, A. Barrado, and A. Lázaro, "Review of the maximum power point tracking algorithms for stand-alone photovoltaic systems," Solar Energy Materials and Solar Cells, vol. 90, no. 11, pp. 1555-1578, Jul. 2006, doi: https://doi.org/10.1016/j.solmat.2005.10.023.

[4] W. T. Rhodes et al., Eds., Photovoltaic Solar Energy Generation, vol. 112. Berlin/Heidelberg: Springer-Verlag, 2005.

[5] P. Mohanty, T. Muneer, and M. Kolhe, Eds., Solar Photovoltaic System Applications: A Guidebook for Off-Grid Electrification. Cham: Springer International Publishing, 2016.

[6] IDEAM and UPME, Atlas de radiación solar, ultravioleta y ozono de Colombia. Bogotá, 2017.

[7] Y. Muñoz Maldonado, M. Pinto Calderón, and et al., Prospectiva energética Colombia 2050, 1st ed. Colombia: Ediciones Universidad Industrial De Santander, 2019.

[8] J. Barbosa, F. Trujillo, P. Velásquez, and J. Castellanos, "Estudio para el uso de la tecnología solar fotovoltaica," Revista Ingeniería Solidaria, vol. 6, no. 10-11, pp. 69-81, 2010, [Online]. Available: https://bit.ly/3lMo4Vh. 
[9] SSPD, "Diagnóstico de la prestación del servicio de energía eléctrica," pp. 1-74, Colombia, 2018. [Online]. Available: https://bit.ly/3jYjGC8.

[10] D. Rodríguez-Urrego and L. Rodríguez-Urrego, "Photovoltaic energy in Colombia: Current status, inventory, policies and future prospects," Renewable and Sustainable Energy Reviews, vol. 92, pp. 160-170, 2018, doi: https://doi.org/10.1016/j.rser.2018.04.065.

[11] O. G. Cucaita Hurtado and I. O. Cabeza Rojas, "Trends in materials engineering for the manufacture of photovoltaic solar cells," Revista Ingeniería Solidaria, vol. 13, no. 23, pp. 151-162, Sep. 2017, doi: https://doi.org/10.16925/in.v13i23.2070.

[12] W. A. Chamorro Coral and S. Urrego Riveros, "Celdas solares orgánicas, una perspectiva hacia el futuro," Elementos, vol. 2, no. 2, pp. 139-149, May 2013, doi: https://doi.org/10.15765/e. v2i2.181.

[13] B. Shiva Kumar and K. Sudhakar, "Performance evaluation of 10MW grid connected solar photovoltaic power plant in India," Energy Reports, vol. 1, pp. 184-192, 2015, doi: https://doi. org/10.1016/j.egyr.2015.10.001.

[14] E. M. Querikiol and E. B. Taboada, "Performance Evaluation of a Micro Off-Grid Solar Energy Generator for Islandic Agricultural Farm Operations Using HOMER," Journal of Renewable Energy, vol. 2018, pp. 1-9, Dec. 2018, doi: https://doi.org/10.1155/2018/2828173.

[15] L. O. Aghenta and M. T. Iqbal, "Design and Dynamic Modelling of a Hybrid Power System for a House in Nigeria," International Journal of Photoenergy, vol. 2019, pp. 1-13, Apr. 2019, doi: https://doi.org/10.1155/2019/6501785.

[16] R. Singh and L. Kaur, "Optimal Configuration and Evaluation Analysis of an Existing Solar Photovoltaic Power Plant," in 2018 International Conference on Renewable Energy and Power Engineering (REPE), Nov. 2018, pp. 47-50, doi: https://doi.org/10.1109/REPE.2018.8657484.

[17] J. Florez, D. Tobón, and G. Castillo, “¿Ha sido efectiva la promoción de soluciones energéticas en las zonas no interconectadas (ZNI) en Colombia?," Cuadernos de administración, vol. 22, no. 38, pp. 219-245, 2009, [Online]. Available: https://bit.ly/3nR0Orb.

[18] J. Hernandez, C. L. Trujillo, and F. Santamaria, "Photovoltaic projects developed in NonInterconnected Zones in Colombia," in 2015 IEEE 42nd Photovoltaic Specialist Conference (PVSC), Jun. 2015, pp. 1-6, doi: https://doi.org/10.1109/PVSC.2015.7356258. 
[19] F. Nieuwenhout et al., "Monitoring and evaluation of Solar Home Systems. Experiences with applications of solar PV for households in developing countries," Netherlands, ECN-C--00-089, 2000. [Online]. Available: https://bit.ly/3j13ZZw.

[20] E. N. A. AlShemmary, L. M. Kadhom, and W. J. Al-Fahham, "Information Technology and Stand-alone Solar Systems in Tertiary Institutions," Energy Procedia, vol. 36, pp. 369-379, 2013, doi: https://doi.org/10.1016/j.egypro.2013.07.042.

[21] F. Cuadros, F. López-Rodríguez, A. Marcos, and J. Coello, "A procedure to size solar-powered irrigation (photoirrigation) schemes,” Solar Energy, vol. 76, no. 4, pp. 465-473, Apr. 2004, doi: https://doi.org/10.1016/j.solener.2003.08.040.

[22] Y.-O. N. Udoakah, E. E. Nta, I. E. Okon, and U. E. Akpabio, "Design of a 1 kva PV system for electrical laboratory in faculty of engineering, University of Uyo, Nigeria," in IEEE Global Humanitarian Technology Conference (GHTC 2014), Oct. 2014, pp. 1-5, doi: https://doi. org/10.1109/GHTC.2014.6970252.

[23] V. C. Sontake and V. R. Kalamkar, "Solar photovoltaic water pumping system - A comprehensive review," Renewable and Sustainable Energy Reviews, vol. 59, pp. 1038-1067, Jun. 2016, doi: https://doi.org/10.1016/j.rser.2016.01.021.

[24] R. Goura, "Analyzing the on-field performance of a 1-megawatt-grid-tied PV system in South India," International Journal of Sustainable Energy, vol. 34, no. 1, pp. 1-9, Jan. 2015, doi: https://doi.org/10.1080/14786451.2013.824880.

[25] G. Makrides, B. Zinsser, M. Norton, G. E. Georghiou, M. Schubert, and J. H. Werner, "Potential of photovoltaic systems in countries with high solar irradiation," Renewable and Sustainable Energy Reviews, vol. 14, no. 2, pp. 754-762, Feb. 2010, doi: https://doi.org/10.1016/j. rser.2009.07.021.

[26] S. Salazar and Y. Muñoz, "Análisis de los aspectos técnicos e impactos socioeconómicos de sistemas de generación aislada, a partir de energía fotovoltaica en Zonas No Interconectadas de Colombia," Universidad Autónoma de Bucaramanga, 2017.

[27] E. B. Rúa Ramírez, A. I. Barrera Siabato, and M. Gómez Orduz, "Analisis tecnico, socioeconomico y ambiental de la electrificación con energía solar fotovoltaica aislada para vivienda rural en Hato Corozal, Casanare, Colombia," Revista de Investigación Agraria y Ambiental, vol. 8, no. 1, pp. 239-248, Jun. 2017, doi: https://doi.org/10.22490/21456453.1853.

[28] Magna, "MA12-100 (12V100AH)," pp. 1-33, 2016. [Online]. Available: https://bit.ly/2H194nw. 
14 System for performance assessment of solar home systems

[29] M. P. Aparicio, Energía solar fotovoltaica: cálculo de una instalación aislada, 2nd ed. MARCOMBO, 2010.

[30] Eusko Ikaskuntza, "Diseño, dimensionado y selección de componentes de instalaciones fotovoltaicas," pp. 1, 2019. [Online]. Available: https://bit.ly/3kdcvq5 (accessed Oct. 14, 2019). 